\title{
An in vitro rumen-mimetic continuous cultivation system for evaluating the nutritional value of micropulverized roughage based on volatile fatty acid production
}

\author{
Hitosi Agematu $^{1 *}$, Takehiko Takahashi ${ }^{2}$ and Yoshio Hamano ${ }^{3,4}$ \\ ${ }^{1}$ Akita National College of Technology, Department of Applied Chemistry, Akita, Japan \\ ${ }^{2}$ Akita Prefectural University, Faculty of Systems Science and Technology, Department of Mechanical Engineering, Yurihonjo, Akita, Japan \\ ${ }^{3}$ Akita Prefectural University, Faculty of Bioresource Sciences, Field Education and Research Center, Ohgata, Akita, Japan \\ ${ }^{4}$ Kitasato University, Faculty of Veterinary Medicine, Department of Animal Science, Towada, Aomori, Japan
}

\begin{abstract}
In order to avoid ruminal acidosis, increasing the amount of energy supplied from roughage (high-cellulose diets) should be considered. The objective is to develop a novel in vitro procedure to evaluate the contribution of micropulverized roughage for which the nutritional value was increased. Ruminal bacteria collected from a Japanese shorthorn cow were continuously cultivated for over 60 days at $\mathrm{pH} 6.5 \mathrm{using}$ artificial saliva and used to evaluate the nutritional value of 10 or $20 \mathrm{~g}$ of dried roughage. The digestion of roughage was monitored using a pH meter to detect the beginning and end of digestion, and the amounts of VFAs (i.e., acetic, propionic, and butyric acids) produced during the digestion were determined by HPLC. The nutritional value (mol-VFAs/kg-substrate; mean $\pm \mathrm{SE}$ ) of microcrystalline cellulose, Italian ryegrass silage, rice straw, alfalfa hay, and micropulverized Japanese cedar were 6.76 $\pm 0.25,4.64 \pm 0.10,3.05 \pm 0.20,1.52 \pm 0.09$, and $0.88 \pm 0.10$ respectively. By micropulverizing rice straw to an average particle diameter of $20-50 \mu \mathrm{m}$, the value of this processed roughage was increased by $135 \%$ (4.11 \pm 0.27 ). During cultivation, ruminal bacteria were observed to form biofilms on the surface of feed fragments. The micropulverized roughage became enveloped by these biofilms and was digested by the microbiota growing synergistically within. The digestible nutrients of $20 \mathrm{~g}$ of roughage were completely digested by feed particleassociated bacteria within approximately $24 \mathrm{~h}$.
\end{abstract}

The microbiota constituted a cellulose metabolic pathway for the conversion of roughage to VFAs. The in vitro procedure measures the accessibility of cellulolytic bacteria to the cellulose of roughage and the amount of digestible cellulose contained in roughage. The procedure is suitable for evaluating the nutritional value of micropulverized roughage and will accelerate the development of it for use in animal feed.

\section{Introduction}

The current production systems for milk and meat in Japan demand increasing more individual production to lower housing costs per unit of milk or meat produced. Therefore, non-structural carbohydrates (starch and sugars) have been used as the main energy source in diets. Many animals are being fed significant amounts of concentrate (high-starch diets) while grazed in pastures. However, feeding with readily fermentable starch can cause a rapid depression in ruminal $\mathrm{pH}$ due to the accumulation of volatile fatty acids (VFAs, primarily acetic, propionic, and butyric acids) and lactic acid within the rumen [1]. The potential for acidification of the rumen depends on the concentration of starch in the diet and its ruminal degradation rate. A ruminal $\mathrm{pH}$ of below 5.6 for $3-5 \mathrm{~h} \mathrm{day}^{-1}$ is defined as subacute ruminal acidosis (SARA), a condition that is associated with deleterious health effects in animals, including reduced fiber digestion, diarrhea, laminitis, and liver abscesses [1,2]. The development of SARA in dairy cows can cause economic losses due to reductions in milk and milk fat production, while the disorder does not present specific signals or symptoms. Therefore, in order to prevent the development of SARA in cattle, the energy supply derived from concentrates should be limited. Degradation of the cell wall carbohydrates (cellulose and hemicellulose) in plant fibers is fundamental to ruminant digestion. Increasing the amount of energy supplied from roughage should be considered. In this regard, the following three points are important. (i) The bulk specific gravity $\left(\mathrm{kg} / \mathrm{m}^{3}\right)$ of roughage should be increased to increase its intake because the microbial digestive capacity of the rumen depends on ruminal volume. (ii) The surface area $\left(\mathrm{m}^{2} / \mathrm{kg}\right)$ of roughage should be increased to provide a greater surface area for bacterial attachment for digestion. (iii) An appropriate amount of crude protein should be fed with roughage to increase its digestibility. These requirements can be satisfied by micropulverizing a mixture of roughage and crude protein sources. The amount of energy supplied from roughage could be increased by micropulverization of roughage [3,4]. However, rumination must be normally maintained by conventional roughage intake because the volume of daily saliva produced depends directly on chewing time. Reduced chewing and rumination have been shown to be associated with a risk of SARA development as a result of decreased

*Correspondence to: Hitosi Agematu, Akita National College of Technology, Department of Applied Chemistry, Akita, Japan, Tel: +81-18-847-6063; Fax: +81-18-847-6066; E-mail: agematu@akita-nct.ac.jp

Key words: in vitro procedure, rumen-mimetic, roughage, volatile fatty acid

Received: May 18, 2019; Accepted: May 22, 2019; Published: May 28, 2019 
saliva buffering of the ruminal content [5]. Therefore, micropulverized roughage should be considered as a component of concentrate or total mixed ration (TMR) to reduce provision of high-starch diets. To facilitate further developments in roughage processing, an in vitro procedure is needed to evaluate the nutritional value of micropulverized roughage.

Conventional in vitro evaluation techniques can be classified as follows: (i) methods that measure the disappearance of feed using a nylon filter or nylon bag [6-8]; and (ii) methods that measure gas production from feed fermentation [9]. However, the disappearance of feed in vitro may not accurately reflect with the ruminal digestion of feed because cell contents and minerals are soluble in water and particle sizes are often sufficiently small to enable their passage through a filter bag during fermentation. Accordingly, the nylon bag technique cannot be used for micropulverized roughage because this material passes through a nylon bag.

Furthermore, the assumption that gas (mainly $\mathrm{CO}_{2}$ and $\mathrm{CH}_{4}$ ) production is linearly related to the rate and extent of feed digestion is questionable, because methane produced from feed fermentation is influenced by the molar proportion of fermentation products in the rumen (more acetate and less reduced fermentation products such as lactate and propionate). Carbon dioxide is also released from the buffered incubation media via the acid dissociation $\left(\mathrm{p} K_{a}=6.3\right)$ of bicarbonate.

The objective of this study was to develop a novel in vitro procedure to facilitate evaluation of the nutritional value of micropulverized roughage, based on a rumen-mimetic continuous cultivation technique. The advantage of this procedure is that it enables determination of the amounts of acetic, propionic, and butyric acids produced by ruminal bacteria that completely digest the digestible nutrients of roughage even if it is micropulverized and that it does not need to collect rumen fluid for each experiment. In order to demonstrate how the system relates to the metabolic pathway from cellulose to VFAs, we monitored the diversity of the bacterial community associated with the system via denaturing gradient gel electrophoresis (DGGE) analysis and PCR assays of PCR-amplified 16S rDNA fragments.

\section{Material and method}

\section{Sampling of rumen fluid}

All experimental protocols were approved by the Animal Care and Use Committee of Akita Prefectural University (Ohgata, Akita, Japan). For the purpose of this study we used a Japanese shorthorn non-pregnant and lactating cow (496 kg of body weight, 37 months old) as the donor animal for ruminal fluid. The cow was fed $5 \mathrm{~kg}$ of hay (dry matter [DM] basis) and $0.65 \mathrm{~kg}$ of concentrate mixture (rice, barley, rice bran, and soybean meal; DM basis) twice daily at 08:30 and 16:00 h. Approximately $1 \mathrm{~L}$ of rumen fluid was anaerobically collected from the cow using a stainless-steel oral catheter for cattle (Sanshin Industrial Co. Ltd., Kanagawa, Japan) and was transferred to a glass bottle at 14:00 h. The bottle was immediately filled with $\mathrm{O}_{2}$ free $\mathrm{CO}_{2}$ gas and was maintained at a temperature of $39 \mathrm{C}$. And then, the rumen fluid was transferred to our laboratory in Akita National College of Technology within $1 \mathrm{~h}$.

\section{The rumen-mimetic continuous cultivation system}

The rumen-mimetic continuous cultivation was simultaneously carried out in reactor A and B from $1 \mathrm{~L}$ of rumen fluid (Figure 1).
Reactor A and B were used for digestion trials independently. In each fermentation reactor, approximately $500 \mathrm{~mL}$ of the rumen fluid was diluted with $1,500 \mathrm{~mL}$ of artificial saliva containing (per liter) $10.6 \mathrm{~g}$ of $\mathrm{NaHCO}_{3}, 0.57 \mathrm{~g}$ of KCl, $4.7 \mathrm{~g}$ of $\mathrm{Na}_{2} \mathrm{HPO}_{4} \cdot 12 \mathrm{H}_{2} \mathrm{O}, 0.12 \mathrm{~g}$ of $\mathrm{MgSO}_{4} \cdot 7 \mathrm{H}_{2} \mathrm{O}$, $0.04 \mathrm{~g}$ of $\mathrm{CaCl}_{2} \cdot 2 \mathrm{H}_{2} \mathrm{O}, 0.56 \mathrm{~g}$ of urea, and $1.0 \mathrm{~g}$ of $\left(\mathrm{NH}_{4}\right)_{2} \mathrm{SO}_{4}$, given a working volume of $2.0 \mathrm{~L}$. The cultivation of ruminal microorganisms was carried out anaerobically by intermittent ventilation with nitrogen gas (99.9\% nitrogen) produced using a Model O2B System nitrogen gas generator (System Instruments Co., Ltd., Tokyo, Japan) at an incubation temperature of $39^{\circ} \mathrm{C}$. To promote solid-liquid separation in the reactor, the contents were slowly agitated at 30-40 rpm using two four-bladed impellers. Ten or twenty grams of microcrystalline cellulose [102331; Merck KGaA, Darmstadt, Germany; $20-160 \mu \mathrm{m}$ ( $\geq 80 \%)$ ] or roughage was added to the reactor as a carbon source to determine its nutritional value. During cultivation, the $\mathrm{pH}$ of the culture solution was recorded and maintained at a value above 6.50 via the automatic addition of alkaline artificial saliva (described above) using one channel of a twoflow channel peristaltic pump. Simultaneously the same volume of culture suspension was withdrawn from the upper layer of the reactor as effluent via a setting bottle and the other channel of the peristaltic pump. The addition of artificial saliva and the removal of the same volume of culture suspension were regulated using a DJ-1023 pH metercontroller (ABLE Co., Tokyo, Japan). The amounts of VFAs (i.e., acetic, propionic, and butyric acids) in the collected effluent were determined by HPLC analysis. The nutritional value of roughage was expressed as the total mol number of VFAs produced from $1 \mathrm{~kg}$ of substrate (molVFAs/kg-substrate). To analyze microbial community structure in the reactor, $10 \mathrm{~mL}$ of the reactor contents was collected before daily feeding and preserved at $-20^{\circ} \mathrm{C}$.

\section{Preparation of roughage}

We determined the nutritional value of 10 or $20 \mathrm{~g}$ (DM) of rice straw, alfalfa hay, Italian ryegrass silage, and Japanese cedar (Cryptomeria japonica D. Don). Italian ryegrass silage was supplied by Dr. E. Touno (National Agriculture and Food Research Organization, Morioka, Japan). The roughage was pulverized using a WB-1blender (WARING, Torrington, USA). The particle size obtained based on sieve

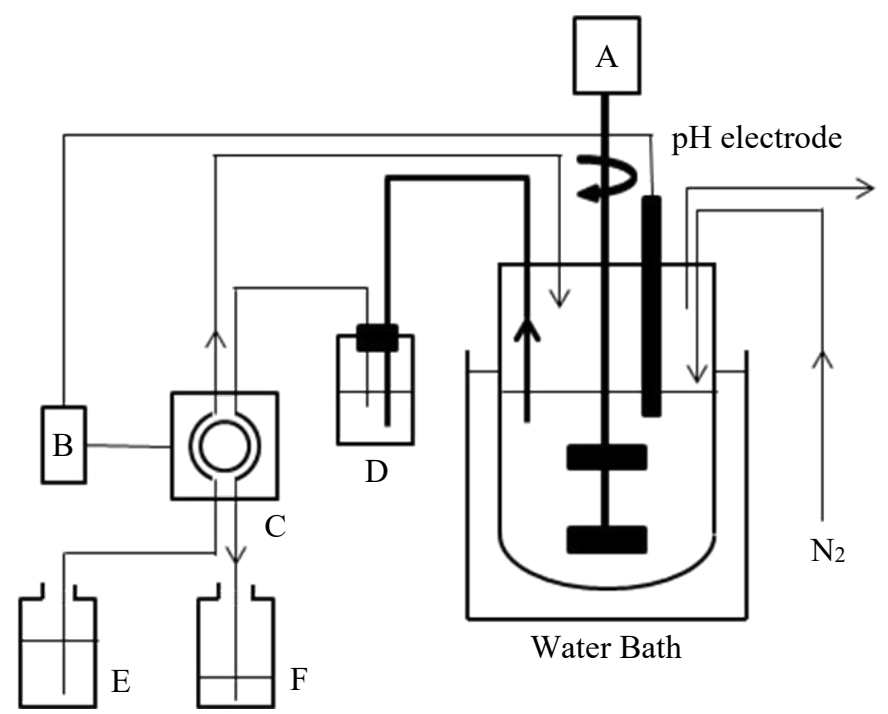

Figure 1. Rumen-mimetic continuous cultivation system.

A: Agitator; B: pH meter-controller; C: Two-flow channel peristaltic pump; D: Setting bottle; E: Artificial saliva; F: Effluent 
analysis was $0.1-1.0 \mathrm{~mm}(80 \%)$. Moreover, rice straw and Japanese cedar were micropulverized under dry conditions by a tandemring mill [10]. The average particle diameter of the micropulverized powder was $20-50 \mu \mathrm{m}$.

\section{High-performance liquid chromatography (HPLC) analysis}

The amounts of acetic, propionic, and butyric acids in the reactor effluents were determined using a Nexera UHPLC system (Shimadzu Corp., Kyoto, Japan) equipped with a diode array ultraviolet detector set at $210 \mathrm{~nm}$ and an InertSustain C18 column $(2 \mu \mathrm{m}, 75 \times 2.1 \mathrm{~mm}$ i.d., GL Science Inc., Tokyo, Japan). A $2-\mu \mathrm{L}$ HPLC sample was analyzed using a linear concentration gradient of acetonitrile in $20 \mathrm{mM}$ phosphate buffer ( $\mathrm{pH} 2.5)$ from $1 \%(\mathrm{v} / \mathrm{v})$ to $40 \%(\mathrm{v} / \mathrm{v})$ for $5 \mathrm{~min}$ at a flow rate of $0.3 \mathrm{~mL} / \mathrm{min}$ at $40^{\circ} \mathrm{C}$. For preparation of samples for HPLC sample, 200 $\mu \mathrm{L}$ of $200 \mathrm{mM}$ phosphate buffer ( $\mathrm{pH} 2.5$ ) was added to $200 \mu \mathrm{L}$ of the supernatant of the effluent. This mixture was centrifuged at $15,000 \times g$ for $5 \mathrm{~min}$ and the resulting supernatant was used for HPLC. Retention times of lactic, acetic, propionic, and butyric acids were 1.04, 1.11, 2.59, and 4.34 minute, respectively, in the HPLC conditions described above.

\section{Extraction of bacterial DNA}

A total of $10 \mathrm{~mL}$ of frozen reactor content was defrosted and then incubated on ice to separate the liquid phase from the solid phase. Total DNA was extracted from the liquid phase using an ISOPLANT II DNA extraction kit (NIPPON GENE CO., LTD., Tokyo, Japan) according to the DNA extraction protocol provided by the manufacturer. The final concentration of DNA was adjusted to 10 $\mathrm{ng} / \mu \mathrm{L}$.

\section{PCR-amplification of $16 S$ rDNA}

For DGGE analysis, bacterial 16S rDNA was amplified from the extracted DNA using the primer pair GC-357F (5'-CGCCCGCCGC GCGCGGCGGGCGGGGCGGGGGCACGGGGGGCCTACGGGA GGCAGCAG-3') and 518R (5'-GTATTACCGCGGCTGCTGG-3') [11]. The PCR mixtures contained $20 \mathrm{pmol}$ of each primer, $50 \mathrm{ng}$ of template DNA, and $20 \mu \mathrm{L}$ of Emerald Amp PCR master mix (Takara Bio INC., Shiga, Japan) in a total volume of $40 \mu \mathrm{L}$. PCR was performed in a GeneAtlas 322 system (ASTEC CO. LTD., Fukuoka, Japan) using the following temperature program: an initial denaturation at $94^{\circ} \mathrm{C}$ for $5 \mathrm{~min}, 94^{\circ} \mathrm{C}$ for $1 \mathrm{~min}$, decreasing temperature gradient from 65 to $55^{\circ} \mathrm{C}$ in $0.5^{\circ} \mathrm{C}$ steps in each cycle for $1 \mathrm{~min}, 72^{\circ} \mathrm{C}$ for $1 \mathrm{~min}$ for 20 cycles, followed by 10 cycles of $1 \mathrm{~min}$ denaturation at $94^{\circ} \mathrm{C}, 1 \mathrm{~min}$ annealing at $55^{\circ} \mathrm{C}$, and $1 \mathrm{~min}$ extension at $72^{\circ} \mathrm{C}$, with a final extension at $72^{\circ} \mathrm{C}$ for $7 \mathrm{~min}$.

For PCR assays, the following species-specific primer pairs were used to amplify partial $16 \mathrm{~S}$ rDNA sequences: for Fibrobacter succinogenes, Fs586f (5'-GTTCGGAATTACTGGGCGTAAA$\left.3^{\prime}\right)$ and Fs706r (5'-CGCCTGCCCCTGAACTATC-3') [12], Fs219f (5'-GGTATGGGATGAGCTTGC-3') and Fs654r(5'GCCTGCCCCTGAACTATC-3') [13]; and for Ruminococcus flavefaciens, Rf96f (5'-CGAACGGAGATAATTTGAGTTTACTTAGG$\left.3^{\prime}\right)$ and Rf220r (5'-CGGTCTCTGTATGTTATGAGGTATTACC-3') [12], and Rf154f (5'-TCTGGAAACGGATGGTA-3') and Rf425r(5'CCTTTAAGACAGGAGTTTACAA-3') [13]; and for Ruminococcus albus, Ra1281f (5'-CCCTAAAAGCAGTCTTAGTTCG-3') and Ra1439r (5'-CCTCCTTGCGGTTAGAACA- $3^{\prime}$ ) [13]. The PCR conditions were as follows: $30 \mathrm{~s}$ at $94^{\circ} \mathrm{C}$ for denaturing, $30 \mathrm{~s}$ at $60^{\circ} \mathrm{C}$ for annealing and 30 $\mathrm{s}$ at $72^{\circ} \mathrm{C}$ for extension ( 40 cycles), with the exception of 6 min denaturation in the first cycle and 10 min extension in the final cycle. The amplicons were examined by electrophoresis on $2.0 \%(\mathrm{w} / \mathrm{v})$ agarose gels.

\section{PCR-DGGE analysis}

A total of $5 \mu \mathrm{L}$ of each PCR-amplified 16S rDNA sample was loaded on to an $8 \%$ polyacrylamide gel prepared using a TAE buffer $(20 \mathrm{mM}$ Tris-acetate, $10 \mathrm{mM}$ sodium acetate, $0.5 \mathrm{mM}$ EDTA, $\mathrm{pH}$ 8.0) and with a $30 \%-60 \%$ linear gradient of the denaturants urea and formamide [ $100 \%$ denaturant corresponded to $40 \%(\mathrm{v} / \mathrm{v})$ deionized formamide and $7 \mathrm{M}$ urea]. Electrophoresis was performed using a Bio-Rad DCode system (Bio-Rad Laboratories, Inc., CA, USA) at $60^{\circ} \mathrm{C}$ and $130 \mathrm{~V}$ for 5 h. DGGE Marker III (Nippon Gene CO., LTD., Toyama, Japan) was loaded into lanes at both ends of each gel. Gels were stained with SYBR Green I (Takara Bio INC., Shiga, Japan) according to manufacturer's instructions, and images were digitally recorded and analyzed using a Gel Doc EZ System and Image Lab software (Bio-Rad Laboratories, Inc., CA, USA).

\section{Statistical analysis}

In the experiments to assess day-to-day variations and reactor-toreactor variations of the procedure, the data were analyzed for statistical significances using Student's $t$-test (KaleidaGraph, Synergy Software). Difference was assessed with two-side test with an a level of 0.05 . The coefficient of variation $(\mathrm{CV})$ was also used as precision index.

\section{Result}

\section{The rumen-mimetic continuous cultivation system}

Ruminal bacteria were continuously cultivated for over 60 days under anaerobic conditions and used to determine the nutritional value of roughage, which was expressed in terms of the total amount of VFAs produced. VFA production was monitored using a $\mathrm{pH}$ meter, which facilitated assessment of the digestion activity of the ruminal bacteria as the $\mathrm{pH}$ value decreased. With the exception of the supplemented ammonium sulfate, the composition of the artificial saliva is fundamentally similar to that of sheep and calves [14]. The nitrogen sources were replenished via the addition of artificial saliva as the $\mathrm{pH}$ decreased. The process was regulated via a $\mathrm{pH}$ meter-controller. When $10 \mathrm{~g}$ of microcrystalline cellulose was added to the reactor, the $\mathrm{pH}$ of the culture solution was immediately decreased as a consequence of VFA production (Figure 2). It is known that ruminal bacteria rapidly attach to and digest recently integrated feed particles [15]. And then the $\mathrm{pH}$ was regulated at 6.50 by the addition of artificial saliva. After approximately $20 \mathrm{~h}$, the $\mathrm{pH}$ exceeded 6.50 as a consequence of the cessation in VFA production. Accordingly, the beginning and end of feed digestion were indicated by a decrease and increase in $\mathrm{pH}$, respectively. The amounts of acetic, propionic, and butyric acids in the effluent, that was withdrawn from the reactor between the beginning and end of feed digestion, were determined by HPLC analysis. Acetic, propionic, and butyric acids were the predominant VFAs in the effluent, whereas no lactic acid was detected. The reproducibility of the procedure was examined using microcrystalline cellulose (Table 1). The experiments were conducted on separate days within 60 days to assess day-to-day variations and using reactor A or B to determine reactorto-reactor variations. As shown in Table 1, there were no statistically significant differences if compared each data of reactor A and B ( $p>$ 0.05 ). The nutritional values (mol-VFAs $/ \mathrm{kg}$-substrate; mean $\pm \mathrm{SD}$ ) of $20 \mathrm{~g}$ of microcrystalline cellulose obtained using reactor A and B were $6.75 \pm 1.15$ and $6.76 \pm 1.17$, respectively $(p=0.964)$, and the coefficients of variation $(\mathrm{CV}, \%)$ of these data were 17.0 and 17.3 , respectively. The reproducibility of $20 \mathrm{~g}$-digestion was higher than that of $10 \mathrm{~g}$-digestion. During cultivation, the ruminal bacteria formed flocs and biofilms on the surface of feed (Figure 3). The flocs enveloped some of the feed 


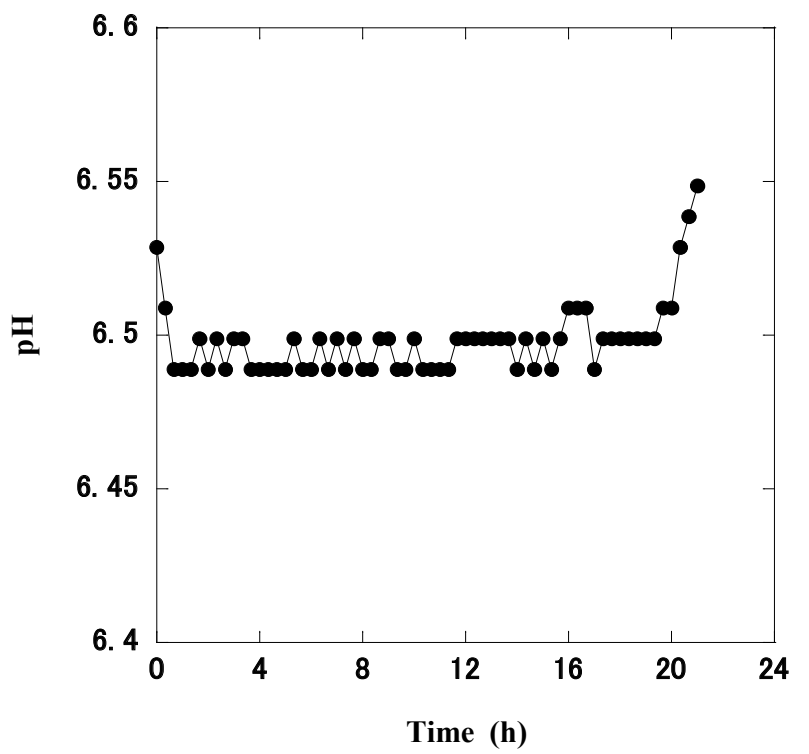

Figure 2. Typical pH pattern observed during the digestion of microcrystalline cellulose. Microcrystalline cellulose (10g) was added, and the pH was recorded in 20-minute intervals. The $\mathrm{pH}$ was regulated so as not to decrease below 6.50 via the automatic addition of the artificial saliva

Table 1. The day-to-day variations and the reactor-to-reactor variations of the in vitro procedure using 10 or $20 \mathrm{~g}$ of microcrystalline cellulose

\begin{tabular}{|c|c|c|c|c|c|c|}
\hline Cellulose (g) & \multicolumn{2}{|c|}{10} & & \multicolumn{2}{|c|}{20} & \\
\hline Reactor & $\mathbf{A}$ & B & & $\mathbf{A}$ & B & \\
\hline $\mathbf{n}^{\mathrm{a}}$ & 11 & 23 & $p$-value & 28 & 21 & $p$-value \\
\hline Acetic acid $(\mathrm{mmol})$ & $41.1 \pm 10.1$ & $40.9 \pm 10.0$ & 0.948 & $78.3 \pm 21.8$ & $79.8 \pm 17.1$ & 0.893 \\
\hline Propionic acid (mmol) & $24.8 \pm 5.7$ & $22.0 \pm 5.8$ & 0.202 & $50.0 \pm 9.9$ & $47.5 \pm 11.0$ & 0.427 \\
\hline Butyric acid (mmol) & $4.7 \pm 2.2$ & $3.4 \pm 1.9$ & 0.087 & $6.8 \pm 2.0$ & $7.9 \pm 3.8$ & 0.198 \\
\hline Total VFA $^{\mathrm{b}}(\mathrm{mmol})$ & $70.6 \pm 14.8$ & $66.2 \pm 14.7$ & 0.725 & $135.1 \pm 23.0$ & $135.3 \pm 23.4$ & 0.976 \\
\hline Total VFA ${ }^{\mathrm{b}}(\mathrm{mol} / \mathrm{kg})$ & $7.06 \pm 1.48$ & $6.62 \pm 1.47$ & 0.433 & $6.75 \pm 1.15$ & $6.76 \pm 1.17$ & 0.964 \\
\hline $\mathrm{CV}^{\mathrm{c}}(\%)$ & 21.0 & 22.2 & & 17.0 & 17.3 & \\
\hline
\end{tabular}

Values represent means $\pm \mathrm{SD}$. Student's t-test was used to compare left two values.

${ }^{a}$ Number of separate trials.

${ }^{\mathrm{b}}$ Total VFA is the combined amount of acetic, propionic, and butyric acids.

${ }^{c}$ Coefficient of variation of total VFA.

particles of microcrystalline cellulose and micropulverized feeds. We observed that protozoa disappeared from the culture solution at an early stage of cultivation.

\section{PCR-DGGE analysis of microbial community structure}

Throughout a cultivation period of 55 days, we analyzed the microbial community structure of cultures by PCR-DGGE (Figure 4). The band profiles shown in the DGGE gels reflect the predominant bacterial species in the samples. Visual comparison of the banding patterns indicates that a relatively stable community that is distinct from the initial community structure had formed after 1 week of cultivation, although there was some variation observed in the strength of different bands. Figure 4 shows that certain prominent bands (bands 1 to 8 ) appeared in multiple lanes, and therefore we extracted and sequenced these eight major DGGE bands [16]. The 16S rDNA sequence of band 6 shows high similarity with that of Succiniclasticum ruminis SE10 (98\%) isolated from rumen. The sequences obtained from bands 2 and 5 correspond with those of Prevotella ruminicola Bryant 23 (93\%) and F. succinogenes HM2 (89\%), respectively, which have also previously been isolated from rumen. The $16 \mathrm{~S}$ rDNA sequences of band 2, 5, and 6 have been submitted to the DDBJ/EMBL/GenBank databases under accession number LC199891, LC199895, and LC199896, respectively. The similarities of the 16S rDNA sequences of the other bands were, however, less than $90 \%$, and the closest sequences for these were obtained from strains isolated from sources other than the rumen [16].

\section{PCR assays for cellulolytic bacteria}

The most abundant cellulolytic bacterial species in the rumen are considered to be F. succinogenes, $R$. albus, and R. flavefaciens [17]. We found that the species-specific primer pairs for each of these cellulolytic species successfully amplified the target $16 \mathrm{~S}$ rDNAs from all bacterial DNA extracts, thereby indicating that all three of these bacterial species were continuously cultivated in the fermentation reactor.

\section{Nutritional evaluation of roughage}

In this study, we evaluated the nutritional value of rice straw, alfalfa hay, Italian ryegrass silage, and Japanese cedar (Table 2). Rice straw, alfalfa hay, and Japanese cedar were selected as typical grass, legume, and wood roughage sources, respectively. To simulate the chewing and rumination of cows, we pulverized these materials in a blender. Furthermore, rice straw and Japanese cedar were micropulverized using a tandem-ring mill to examine the effect of particle size on substrate digestibility. In line with expectations, the nutritional value of micropulverized rice straw was observed to be $135 \%$ higher than that of pulverized rice straw. Although the pulverized Japanese cedar remained undigested, micropulverized Japanese cedar was digested by ruminal bacteria to produce VFAs. 

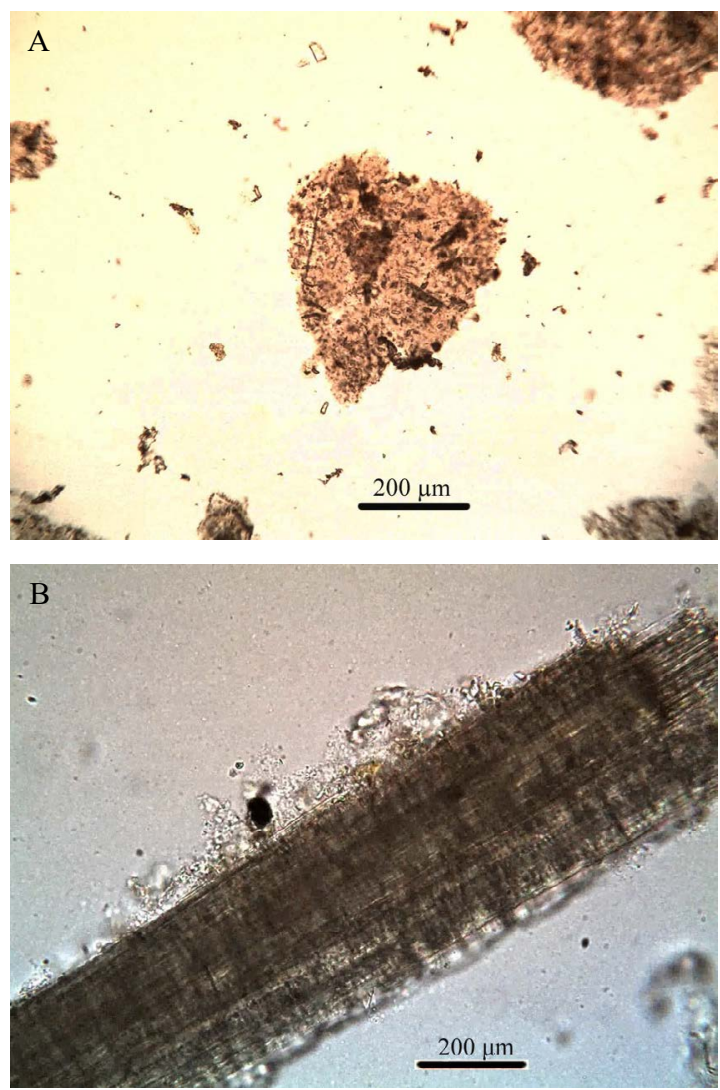

Figure 3. Representative images of flocs (A) and biofilms (B) of ruminal bacteria formed during continuous cultivation. Scale Bar: $200 \mu \mathrm{m}$

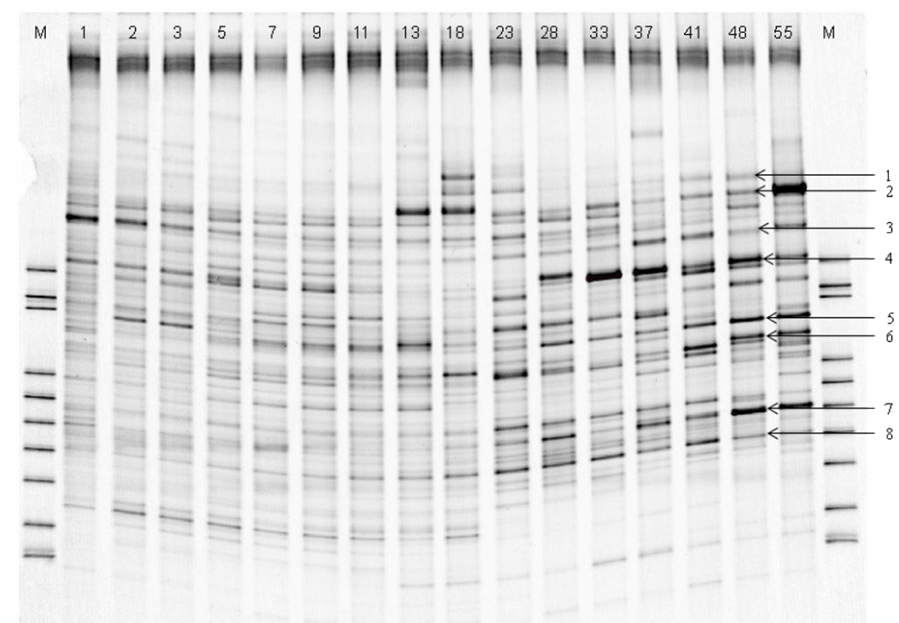

Figure 4. DGGE profile of bacterial $16 \mathrm{~S}$ rDNA in the microbial community of the continuous cultivation. The time course of the cultivation is indicated above the lanes in days. The numbered bands (bands 1 to 8 ) were selected for sequencing. M: DGGE Maker Ш

\section{Kinetics of feed digestion}

The procedure also provided information regarding the kinetics of feed digestion. When $10 \mathrm{~g}$ of microcrystalline cellulose was added to the reactor after an interval of 2 days, we observed that there was a time lag of $7.5 \mathrm{~h}$ between the addition of substrate and the start of its digestion (Figure 5A). However, in the second trial conducted shortly after the first, substrate digestion started immediately (Figure 5A). The maximum digestion rates $(\mathrm{pH}$ reduction rate, $-\mathrm{pH} / \mathrm{h})$ of the first and second trials were 0.0744 and 0.0605 , respectively. When $20 \mathrm{~g}$ of alfalfa hay was added to the reactor, we observed two different digestion rates of 0.0663 and 0.0140 (Figure 5B).

\section{Discussion}

\section{The rumen-mimetic continuous cultivation system}

The novel procedure developed in this study comprises a rumenmimetic continuous cultivation system operated under well-defined conditions. When using this system, cultivation is regulated via a $\mathrm{pH}$ meter-controller to provide all of the chemically defined nutritional requirements of the bacterial population, with the exception of carbon source, and to remove fermentation products such as VFAs. Supplementation of the artificial saliva with urea and ammonia as nitrogen sources means that the procedure is applicable to any roughage that lack sufficient crude protein, such as cellulose powder and wood. Most of the ruminal bacteria can use ammonia as their sole source of
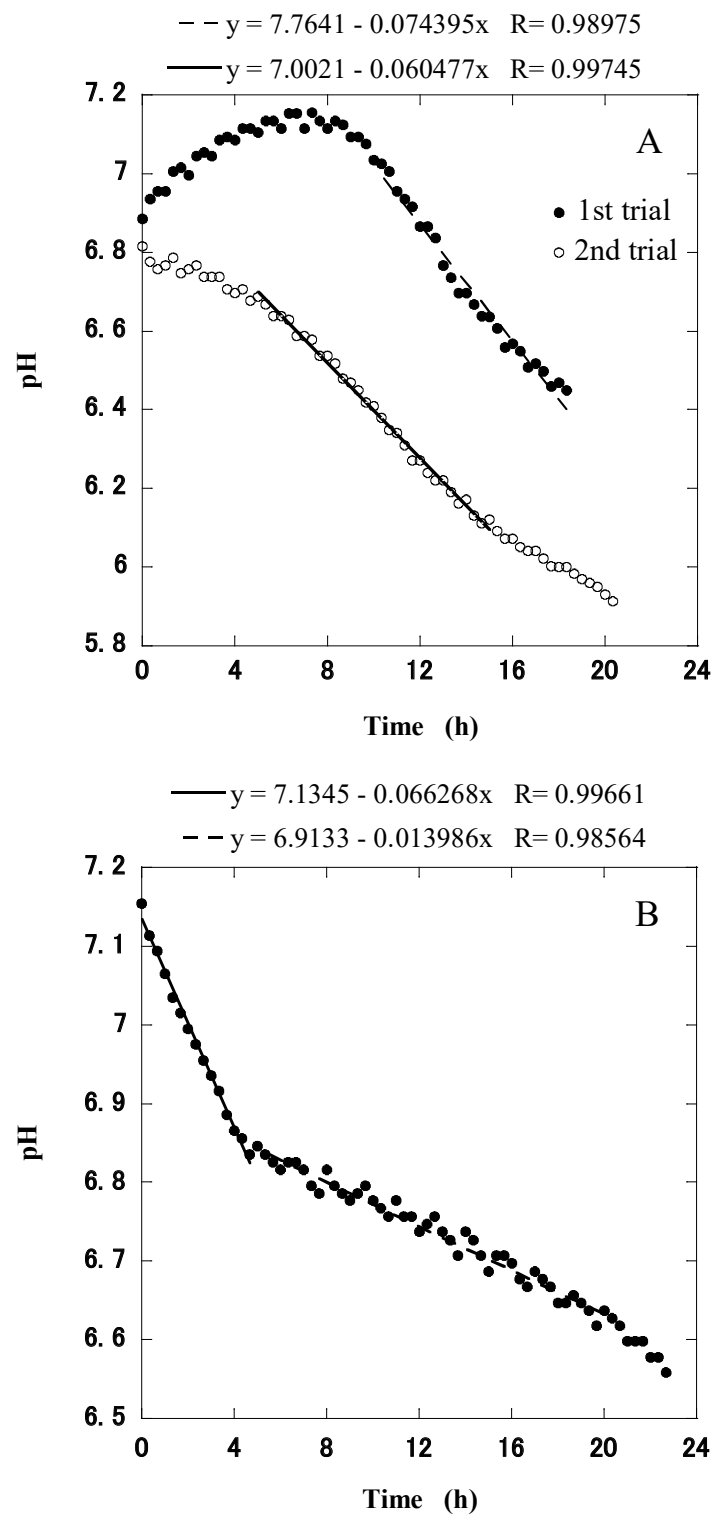

Figure 5. $\mathrm{pH}$ patterns observed during the digestion of microcrystalline cellulose (A) and alfalfa hay (B) 
Agematu H (2019) An in vitro rumen-mimetic continuous cultivation system for evaluating the nutritional value of micropulverized roughage based on volatile fatty acid production

Table 2. Production of acetic, propionic, and butyric acids from roughage using the rumen-mimetic continuous cultivation system

\begin{tabular}{|c|c|c|c|c|c|c|c|}
\hline \multirow{2}{*}{ Rouphage } & \multirow[t]{2}{*}{ Weight(g) } & \multirow[t]{2}{*}{$\mathbf{n}^{\mathbf{a}}$} & \multirow[b]{2}{*}{ Acetic acid } & \multicolumn{2}{|c|}{ Production (mmol) } & \multirow[b]{2}{*}{ Total VFA $^{\mathrm{b}}$} & \multirow{2}{*}{$\begin{array}{c}\text { Total VFA } \\
(\mathrm{mol} / \mathbf{k g})\end{array}$} \\
\hline & & & & Propionic acid & Butyric acid & & \\
\hline Rice straw & 20 & 7 & $34.8 \pm 2.34$ & $22.6 \pm 2.11$ & $3.6 \pm 0.29$ & $61.0 \pm 4.03$ & $3.05 \pm 0.20$ \\
\hline Rice straw * & 20 & 3 & $49.0 \pm 4.12$ & $28.1 \pm 1.29$ & $5.0 \pm 0.15$ & $82.1 \pm 5.34$ & $4.11 \pm 0.27$ \\
\hline \multirow{2}{*}{ Alfalfa hay } & 20 & 4 & $19.9 \pm 0.43$ & $9.0 \pm 1.64$ & $1.6 \pm 0.09$ & $30.4 \pm 1.86$ & $1.52 \pm 0.09$ \\
\hline & 10 & 3 & $10.1 \pm 0.08$ & $4.9 \pm 0.36$ & $0.9 \pm 0.07$ & $15.9 \pm 0.51$ & $1.59 \pm 0.05$ \\
\hline Grass silage & 10 & 3 & $23.9 \pm 2.61$ & $20.1 \pm 2.61$ & $2.4 \pm 0.65$ & $46.4 \pm 1.01$ & $4.64 \pm 0.10$ \\
\hline Japanese cedar* & 20 & 22 & $11.5 \pm 1.37$ & $4.8 \pm 0.60$ & $1.3 \pm 0.10$ & $17.6 \pm 1.93$ & $0.88 \pm 0.10$ \\
\hline
\end{tabular}

Values represent means $\pm \mathrm{SE}$.

${ }^{a}$ Number of separate trials.

b Total VFA is the combined amount of acetic,

propionic, and butyric acids.

" Micropulverized roughage.

nitrogen [18]. Given that the reactor contents were mixed by agitation, the ruminal bacteria had access to sufficient amounts of ammonia as a nitrogen source. Therefore, the supply of a nitrogen source is not a ratelimiting step in roughage digestion in this system. The rate-limiting step of roughage digestion is the accessibility of cellulolytic bacteria to roughage cellulose. Hence, it can be said that the procedure measures the accessibility of cellulolytic bacteria to the cellulose of feed. The increase in surface area of roughage is the key factor regulating the rate of cellulose fermentation. In this regard, we elucidated the effect of micropulverization, using rice straw or Japanese cedar as a substrate (Table 2). Although the nutritional value of roughage will be enhanced by micropulverization, further studies that investigate the ruminal retention time of micropulverized roughage will be needed before it can put into practical use. The nutritional value of rice straw was higher than that of alfalfa hay (Table 2). The reason for this is considered to be that the amount of cellulose (crude fiber) contained in rice straw was more than that in alfalfa hay.

\section{pH indication}

When cellulolytic bacteria depleted digestible carbon sources (cellulose and hemicellulose), there was an apparent cessation of VFA production by ruminal bacteria. Under these conditions, to maintain metabolism, these microorganisms will start to degrade extracellular and/or intracellular proteins (amino acids) via oxidative deamination yielding ammonia and carbon chains that would be subsequently catabolized to VFAs.

Consequently, the $\mathrm{pH}$ of the culture solution increased due to the accumulation of ammonia (Figure 2). As F. succinogenes is a non-proteolytic bacterium, their cultures autolyze even during the growth phase [19]. On the addition of roughage, cellulolytic bacteria immediately commenced digestion of roughage cellulose (Figure 2).

However, under circumstances where cellulose-related catabolism has ceased, it is assumed that a time lag will be necessary prior to the resumption of roughage digestion (Figure 5A). Two digestion rates of alfalfa hay were observed (Figure $5 \mathrm{~B}$ ). Given that approximately onefifth of the weight of alfalfa hay is water-soluble (data not shown), we assume that the first of these rates was associated mainly with the digestion of water-soluble materials and that the second corresponded to the digestion of water-insoluble materials.

\section{Digestion of micropulverized feed in biofilms of ruminal bacteria}

During cultivation, ruminal bacteria were observed to form anaerobic aggregates, or flocs, which are a special type of biofilms.
These biofilms appeared to envelop the micropulverized feed particles, which were of a sufficiently small size, thereby indicating that the micropulverized roughage can be digested in the biofilms attached on the surface of feed fragments. This means that the micropulverized roughage may be successfully retained within the rumen for enough time to be completely digested. The formation of biofilms is advantageous in that it can maximize the synergistic relationships among ruminal bacterial species for conversion of cellulose and nitrogen sources to VFAs and microbial proteins (cells). Notably, the adhesion of ruminal bacteria to plant fibers is an important step in the subsequent digestion of feed, and the bacteria associated with feed particles have been shown to be the major component $(70 \%)$ of the total bacterial population [20,21].

\section{PCR assays and PCR-DGGE analysis}

On the basis of the results of PCR assays, three main cellulolytic bacterial species, F. succinogenes, $R$. albus, and $R$. flavefaciens, were identified as being stably cultivated in the rumen-mimetic system, none of which are proteolytic [17]. F. succinogenes is the most rapidly fibrolytic of all mesophilic bacteria [22]. Digestion of cellulose by these organisms requires the attachment of cells to the cellulose fibers [23,24], and therefore access to the cellulose is essential during the digestion process. Furthermore, PCR-DGGE analysis also detected three rumenrelated bacteria, F. succinogenes, $P$. ruminicola, and S. ruminis. S. ruminis has been shown to metabolize succinate to propionate, while not altering any other energy sources [25], indicating that this organism probably has symbiotic relationships with other ruminal organisms such as F. succinogenes and P. ruminicola. The observations made in the present study indicate that the cultivation system maintained a cellulose metabolic pathway involving cross-feeding among microbes, resulting in a more complete utilization of the feed to yield VFAs as final fermentation products.

\section{Particle size and particle retention time of feed}

Although the size of feed particle influences their digestibility in the rumen of cattle, it is difficult to produce experimental material with the particle size distribution comparable to that produced by the rumination of cattle. Given that most of the feed particles leaving the rumen and found in feces are smaller than $1.14 \mathrm{~mm}$ [18], we processed roughage sources by pulverization using a blender. It is also difficult to simulate particle retention times in the rumen; however, for the purposes of the present system, we defined the roughage retention time as the time necessary for ruminal bacteria to completely digest the digestible nutrients of the roughage. 
Agematu H (2019) An in vitro rumen-mimetic continuous cultivation system for evaluating the nutritional value of micropulverized roughage based on volatile fatty acid production

Table 3. The amounts of catabolic products calculated from the molar productions of VFA

\begin{tabular}{|c|c|c|c|c|c|}
\hline & Cellulose & Grass silage & Rice straw $^{*}$ & Rice straw & Alfalfa hay \\
\hline Total VFA yield $(\mathrm{mmol} / \mathrm{g})^{a}$ & 6.76 & 4.64 & 4.11 & 3.05 & 1.52 \\
\hline Glucose used $(\mathrm{mmol} / \mathrm{g})^{\mathrm{b}}$ & 3.57 & 2.44 & 2.18 & 1.62 & 0.80 \\
\hline Cellulose used $(\mathrm{g} / \mathrm{g})^{\mathrm{c}}$ & 0.578 & 0.395 & 0.353 & 0.262 & 0.130 \\
\hline Gas yield $(\mathrm{mmol} / \mathrm{g})^{\mathrm{d}}$ & 4.70 & 2.87 & 2.95 & 2.10 & 1.16 \\
\hline $\mathrm{CO}_{2}$ yield $(\mathrm{mmol} / \mathrm{g})^{\mathrm{e}}$ & 3.14 & 2.06 & 1.95 & 1.42 & 0.73 \\
\hline $\mathrm{CH}_{4}$ yield $(\mathrm{mmol} / \mathrm{g})^{\mathrm{f}}$ & 1.56 & 0.81 & 1.00 & 0.68 & 0.43 \\
\hline NADH produced $(\mathrm{mmol} / \mathrm{g})^{\mathrm{g}}$ & 6.23 & 3.25 & 3.99 & 2.71 & 1.70 \\
\hline ATP produced $(\mathrm{mmol} / \mathrm{g})^{\mathrm{h}}$ & 17.9 & 12.3 & 10.9 & 8.09 & 4.01 \\
\hline Potential microbial yield $(\mathrm{g} / \mathrm{g})^{\mathrm{i}}$ & 0.179 & 0.123 & 0.109 & 0.081 & 0.040 \\
\hline
\end{tabular}

When the millimolar productions of acetic, propionic, and butyric acids from $1 \mathrm{~g}$ of roughage were $\mathrm{A}, \mathrm{P}$, and $\mathrm{B}$,

respectively, the values were calculated as follows: ${ }^{\mathrm{a}} \mathrm{A}+\mathrm{P}+\mathrm{B},{ }^{\mathrm{b}} 0.5 \mathrm{~A}+0.5 \mathrm{P}+\mathrm{B},{ }^{\mathrm{c}}(0.5 \mathrm{~A}+0.5 \mathrm{P}+\mathrm{B}) \times 0.162,{ }^{\mathrm{d}}$

$\mathrm{A}+2 \mathrm{~B},{ }^{\mathrm{e}} 0.5 \mathrm{~A}+0.25 \mathrm{P}+1.5 \mathrm{~B},{ }^{\mathrm{f}} 0.5 \mathrm{~A}-0.25 \mathrm{P}+0.5 \mathrm{~B},{ }^{\mathrm{g}} 2 \mathrm{~A}-\mathrm{P}+2 \mathrm{~B},{ }^{\mathrm{h}} 2.5 \mathrm{~A}+2.75 \mathrm{P}+3.5 \mathrm{~B},{ }^{\mathrm{i}} 25 \mathrm{~A}+27.5 \mathrm{P}+35 \mathrm{~B}$

at $10 \mathrm{~g}$-cell/mol-ATP [18].

"Micropulverized roughage.

\section{Fermentation balance based on VFA production from glucose}

If the carbohydrate converted to microbial organic matter is ignored, the amounts of certain catabolic products can be stoichiometrically calculated from the molar productions of VFAs based on "fermentation balance" that fully describes the metabolic conversion of glucose to VFAs [26]. These values can be calculated from the molar productions of VFA obtained through the in vitro procedure using the fermentation balance equations [18] (Table 3). The yields of products differ depending on the mole ratio of VFA produced, which in turn will vary according to substrate type and substrate concentration, bacterial community, and fermentation conditions, particularly $\mathrm{pH}$. For example, as shown in Table 2, the mole ratio of propionic acid produced from grass silage was higher than that produced from other roughages examined. Accordingly, the yields of gas (carbon dioxide plus methane), methane, and NADH derived from grass silage were lower than those obtained from micropulverized rice straw, whereas total VFA production from grass silage was higher than that produced from micropulverized rice straw, because propionic acid is a reduced fermentation product. In essence, the greater the ratio of acetic acid and butyric acid to propionic acid, the higher the total yield of gas and the higher the proportion of methane within that gas. Consequently, although gas production is a useful index that reflects the extent of fermentation and energy value of similar feedstuffs, it is not suitable for estimating the amounts of ATP generated or the amounts of microbial mass formed. Potential microbial yield (g) shown in Table 3 was calculated from ATP yield using $\mathrm{Y}_{\text {ATP }}$ (10 g-cell/mol-ATP) [18]. It is important to estimate microbial biomass because it is the major source of protein for the ruminant host animal. In the present study, we estimated that the cellulose used for ATP synthesis (catabolism) was $57.8 \%$ of added cellulose in the digestion of microcrystalline cellulose.

\section{Acknowledgement}

This work was supported by a grant from Japan Society for the Promotion of Science (JSPS KAKENHI Grant Number JP15K14701).

\section{References}

1. Plaizier JC, Krause DO, Gozho GN, McBride BW (2008) Subacute ruminal acidosis in dairy cows: the physiological causes, incidence and consequences. Vet $J$ 176: 21-31. [Crossref]

2. AlZahal O, Kebreab E, France J, McBride BW (2007) A mathematical approach to predicting biological values from ruminal $\mathrm{pH}$ measurements. J Dairy Sci 90: 3777 3785. [Crossref]
3. Hamano Y, Takahashi T, Agematu H (2017) In vitro and in vivo ruminal fermentation of micronised wood powder for volatile fatty acid production in beef cattle. Anim Husb Dairy Vet Sci 1: 1-6.

4. Hamano Y, Takahashi T, Agematu H (2017) Effects of micronized wood powder irradiated with ultraviolet light and exposed to ozone gas on in vitro ruminal fermentation in beef cattle. Anim Husb Dairy Vet Sci 1: 1-7.

5. Kröger I, Humer E, Neubauer V, Reisinger N, Aditya S, et al. (2017) Modulation of chewing behavior and reticular $\mathrm{pH}$ in nonlactating cows challenged with concentraterich diets supplemented with phytogenic compounds and autolyzed yeast. J Dairy Sci 100: 9702-9714. [Crossref]

6. Tilley JMA, Terry RA (1963) A two-stage technique for the in vitro digestion of forage crops. J Brit Grass Soc 18: 104-111.

7. Goering HK, Van Soest PJ (1970) Forage fibre analysis, USDA Agricultural Handbook No 379. (USDA: Washington, DC).

8. Czerkawski JW, Breckenridge G (1977) Design and development of a long-term rumen simulation technique (Rusitec). Br J Nutr 38: 371-384. [Crossref]

9. Menke K, Raab L, Salewski A, Steingass H, Fritz D, et al. (1979) The estimation of the digestibility and metabolizable energy content of ruminant feedingstuffs from the gas production when they are incubated with rumen liquor in vitro. J Agric Sci Camb 93: $217-222$.

10. Takahashi T, Sato Y, Ito K, Mori H (2014) Effect of agitation speed on enzymatic saccharification of dry-pulverized lignocellulosic biomass. Renew Energ 62: 754-760.

11. Muyzer G, de Waal EC, Uitterlinden AG (1993) Profiling of complex microbial populations by denaturing gradient gel electrophoresis analysis of polymerase chain reaction-amplified genes coding for 16S rRNA. Appl Environ Microbiol 59: 695-700.

12. Denman SE, McSweeney CS (2006) Development of a real-time PCR assay for monitoring anaerobic fungal and cellulolytic bacterial populations within the rumen. FEMS Microbiol Ecol 58: 572-582. [Crossref]

13. Koike S, Kobayashi Y (2001) Development and use of competitive PCR assays for the rumen cellulolytic bacteria: Fibrobacter succinogenes, Ruminococcus albus and Ruminococcus flavefaciens. FEMS Microbiol Lett 204: 361-6. [Crossref]

14. KAY RN (1960) The rate of flow and composition of various salivary secretions in sheep and calves. J Physiol 150: 515-537. [Crossref]

15. Lee K, Lee HK, Choi TH, Cho JC (2007) Sejongia marina sp. nov., isolated from Antarctic seawater. Int J Syst Evol Microbiol 57: 2917-2921. [Crossref]

16. Agematu H, Takahashi T, Hamano Y (2017) Continuous volatile fatty acid production from lignocellulose biomass by a novel rumen-mimetic bioprocess. $J$ Biosci Bioeng 124: 528-33. [Crossref]

17. Forsberg CW, Cheng KJ, White BA (1997) Polysaccharide degradation in the rumen and large intestine, In: Mackie RI, White BA (Eds.), Gastrointestinal Microbiology. Chapman and Hall, New York: 319-379.

18. Owens FN, Basalan M (2016) Ruminal Fermentation. In: Millen DD, De Beni Arrigon M, Lauritano Pacheco RD (Eds) Rumenology. Springer-International Publishing, Switzerland: 63-102. 
Agematu H (2019) An in vitro rumen-mimetic continuous cultivation system for evaluating the nutritional value of micropulverized roughage based on volatile fatty acid production

19. Wells JE, Russell JB (1996) Why do many ruminal bacteria die and lyse so quickly? $J$ Dairy Sci 79: 1487-1495. [Crossref]

20. Forsberg CW, Lam K (1977) Use of adenosine 5'-triphosphate as an indicator of the microbiota biomass in rumen contents. Appl Environ Microbiol 33: 528-537. [Crossref]

21. Nagaraja TG (2016) Microbiology of the Rumen. In: Millen DD, De Beni Arrigoni M, Lauritano Pacheco RD (Eds) Rumenology. Springer-International Publishing, Switzerland: $39-61$.

22. Hungate RE (1950) The anaerobic mesophilic cellulolytic bacteria. Bacteriol Rev 14: 1-49. [Crossref]
23. Béra-Maillet C, Ribot Y, Forano E (2004) Fiber-degrading systems of different strains of the genus Fibrobacter. Appl Environ Microbiol 70: 2172-79. [Crossref]

24. Burnet MC, Dohnalkova AC, Neumann AP, Lipton MS, Smith RD, et al. (2015) Evaluating models of cellulose degradation by Fibrobacter succinogenes S85. PLoS One 10: e0143809. [Crossref]

25. van Gylswyk NO (1995) Succiniclasticum ruminis gen. nov., sp. nov., a ruminal bacterium converting succinate to propionate as the sole energy-yielding mechanism. Int J Syst Bacteriol 45: 297-300. [Crossref]

26. Wolin MJ (1960) A theoretical rumen fermentation balance. J Dairy Sci 43: 1452-59.

Copyright: (C2019 Agematu H. This is an open-access article distributed under the terms of the Creative Commons Attribution License, which permits unrestricted use, distribution, and reproduction in any medium, provided the original author and source are credited. 